\title{
Psoriyazisli Kadın Olgularda Genitoüriner Infeksiyonlar; Demografik ve Klinik Özellikler
}

\section{Genitourinary Infections in Female Patients with Psoriasis: Demographic and Clinical Features}

\section{Sevgi Akarsu, Turna İlknur, Ceylan Canbaz Avcı, Saim Çarșanbalı, Özlem Özbağçıvan, Emel Fetil, Ali Tahsin Güneș}

Dokuz Eylül Üniversitesi Tıp Fakültesi, Deri ve Zührevi Hastalıklar Anabilim Dalı, İzmir, Türkiye

\section{Özet}

Amaç: Fokal infeksiyonların psoriyasis lezyonlarının olușumu ve/veya alevlenmesini tetikleyebildiği bildirilmiștir. En sık boğaz infeksiyonları ile ilișkisi bilinmekle birlikte, bazı olgularda aktif veya asemptomatik idrar yolu infeksiyonunun tedavisi ile psoriyazis lezyonlarında da düzelme gözlenmesi üzerine idrar yolu infeksiyonlarının tetikleyici faktör olarak dikkate alınması gerektiği vurgulanmıștır. Bu çalıșmada psoriyazis vulgarisli kadın olgularda genitoüriner infeksiyon (Gül) sıklığının değerlendirilmesi ve Güil olan olgulardaki klinik ve demografik özelliklerin olmayan olgularla karșılaștırılması amaçlanmıștır.

Gereç ve yöntemler: Retrospektif olarak planlanmıș çalıșmamızda kliniğimizde yatan psoriyazis vulgarisli 144 kadın olgunun dosyası psoriyazis klinik tipi, demografik veriler, psoriyazis alan șiddet indeksi ve eșlik eden Güilları açısından taranmıștır. Klinik olarak plak psoriyazisli olgular "stabil", guttat psoriyazisli veya guttat saçılımları olan plak psoriyazisli olgular ise "aktif" psoriyazis olarak tanımlanmıștır. Bulgular: Toplam 144 psoriyazis olgusunun $93(\% 64,6)$ 'ünün aktif psoriyazis, $51(\% 35,4)^{\prime}$ inin ise stabil psoriyazis klinik özelliklerini tașıdığı saptanmıștır. Olguların 31 (\%21,5)'inde idrar yolu infeksiyonu, 23 (\%16)'ünde vajinit ve 5 (\%3,5)'inde servisit olmak üzere toplam $48(\% 33,3)$ olguda GÜl varlığı belirlenmiștir. GÜl saptanan olgularda GÜl olmayanlara göre ortalama psoriasis bașlangıç yașının daha düșük, son alevlenme süresinin daha kısa ve psoriyazis alan șiddet indeksi değerlerinin daha yüksek olduğu gösterilmiștir. Aktif psoriyazisli olgularda \%36.6 olarak saptanan Gül sıklığının stabil psoriyazisli olgulara $(\% 27,5)$ göre daha fazla olduğu ancak istatistiksel olarak anlamlı olmadığı gösterilmiștir.

Sonuç: Hem aktif hem de stabil psoriyaziste özellikle yakın zamanda alevlenme geçirmiș veya klinik șiddet skorları yüksek olan olgularda GÜl araștııılmasının yararlı olacağı kanaatindeyiz. (Türkderm 2011; 45: 174-8)

Anahtar Kelimeler: Psoriyazis, guttat, plak, aktif psoriyazis, stabil psoriyazis, genitoüriner infeksiyon

\section{Summary}

Background and Design: It has been reported that the focal infections may trigger the formation and/or exacerbation of psoriasis lesions. Although it is known that the most frequent association is with throat infection, it is emphasized that urinary tract infections should be considered as a triggering factor due to improvement of psoriatic lesions after treatment of active or asymptomatic urinary tract infection in some cases. The aim of our study was to evaluate the frequency of genitourinary infection (GUI) and to compare the clinical and demographic features of cases with and without GUI.

Materials and methods: In this retrospective study, the files of 144 female psoriasis vulgaris inpatients were evaluated for clinical type of psoriasis, demographic data, psoriasis area and severity index (PASI), and accompanying GUls. Clinically, the patients with plaque psoriasis were defined as "stable" psoriasis, while those with guttate psoriasis or with flare-up of guttate psoriasis in case of plaque psoriasis were defined as "active" psoriasis.

Results: Out of a total of 144 psoriasis patients, 93 (64.4\%) were in the active group and 51 (35.4\%) were in the stable group. Of all the patients, $48(33.3 \%)$ had GUI. Thirty-one (21.5\%) patients had urinary tract infection, $23(16 \%)$ had vaginitis and $5(3.5 \%)$ patients had cervicitis. It was found that the patients with GUI had lower mean age of psoriasis onset, shorter mean duration of the last exacerbation and higher values of mean PASI compared to those without GUI. In patients with active psoriasis, the frequency of GUI was higher (36.6\%) than in the stable group (27.5\%), but statistically significant difference between them was not determined.

Conclusion: We assumed that it would be beneficial to investigate GUI in both active and stable psoriasis cases, especially in patients who had recently suffered an exacerbation or had high clinical severity scores. (Turkderm 201 1; 45: 174-8)

Key Words: Psoriasis, guttate, plaque, active psoriasis, stable psoriasis, genitourinary infection

Yazışma Adresi/Address for Correspondence: Dr. Sevgi Akarsu, Dokuz Eylül Üniversitesi Tıp Fakültesi Hastanesi, Dermatoloji Anabilim Dalı, izmir, Türkiye Tel.: +90 2324123860 E-posta: sevgi.akarsu@deu.edu.tr Geliş Tarihi/Received: 26.03.2011 Kabul Tarihi/Accepted: 02.05.201 1

Türkderm-Deri Hastalıkları ve Frengi Arșivi Dergisi, Galenos Yayınevi tarafından basılımıștır.

Turkderm-Archives of the Turkish Dermatology and Venerology, published by Galenos Publishing. 


\section{Giriş}

Toplumun yaklaşık \%1-3'ünde görülen psoriyazis T hücre aracılı kronik seyirli, tekrarlayıcı ve inflamatuvar bir deri hastalığıdır. Psoriyazisin geniş spektrumlu klinik tabloları arasında en sık görülen tipi olan psoriyazis vulgariste eritemli skuamlı papüler lezyonların büyüklüğü noktasal büyüklükten daha geniş deri yüzeyini kaplayan plaklara kadar değişebilir. ${ }^{1-3}$

Psoriyazis etyopatogenezinde multipl genetik komponentler ve çevresel faktörlerin birlikte rol oynadığı bildirilmiştir. Genetik olarak yatkın kişilerde başııca ilaçlar ve infeksiyonlar olmak üzere çeşitli faktörler psoriyazis lezyonlarını ilk kez ortaya çıkarabileceği gibi mevcut lezyonlarda alevlenmelere de neden olabilir. ${ }^{3.5}$ Çevresel faktörler arasında yer alan infeksiyonların psoriyazis olgularının \%15-76'sında tetikleyici rol oynadığı gösterilmiştir. ${ }^{4 \cdot 9}$ Tetikleyici faktör olarak bildirilen fokal infeksiyonlardan ise özellikle üst solunum yolu infeksiyonlarının rolü olduğundan söz edilmiştir. ${ }^{10-13}$ Bununla birlikte, literatürde idrar kültüründe üreme olan veya asemptomatik idrar yolu infeksiyonu bulunan bazı olguların tedavisi ile psoriyazis lezyonlarındaki dramatik düzelmenin fark edilmesi nedeniyle idrar yolu infeksiyonlarının tetikleyici faktör olarak dikkate alınması gerektiği vurgulanmıştır. Özellikle alt idrar yolu infeksiyonu ve vajinit tablosunun kadınlarda en sık görülen infeksiyonlar arasında bulunduğu bilinmektedir. ${ }^{14,15}$

Literatürde infeksiyonlarla psoriyazis klinik tipleri arasında da ilişki kurulmaya çalışı Imakta olup özellikle guttat psoriyazis ve guttat saçılımlı plak psoriyazisli olgularla daha sıklıkla ilişkilendirildiği görülmektedir. ${ }^{16-20}$ Bu çalışmada kliniğimizde yatırılan psoriyazis vulgarisli kadın olgularda genitoüriner infeksiyon (GÜi) sıklığının belirlenmesine ilaveten, mevcut GÜi varlığının demografik ve klinik özelliklerle ilişkisinin araştırılması amaçlanmıştır.

\section{Gereç ve Yöntemler}

Bu çalışmaya Ocak 2006-Şubat 2011 tarihleri arasında kliniğimizde yatırılmış olan psoriyazis vulgarisli kadın olgular alınmıştır. Son altı ay içinde tedavi türünde değişiklik yapılan veya major bir travma öyküsü olan, bilinen metabolik veya endokrin bir hastalığı ile psoriyazisi tetikleyebilecek herhangi bir ilaç kullanımı öyküsü ve alkolizm öyküsü bulunan, ayrıca dosyalardaki kayıtları eksik olan olgular çalışmaya alınmamıştır.

Retrospektif olarak planlanmış olan bu çalışmada psoriyazis klinik tipi lezyonların morfolojik görünümüne göre belirlenmiş olup; plak psoriyazis (nummular, plak ve/veya plakard lezyonları olanlar), guttat psoriyazis (sadece punktat ve guttat lezyonları olanlar) ve guttat saçıIımları olan plak psoriyazis (nummular, plak ve/veya plakard lezyonların yanında punktat ve/veya guttat lezyonları olanlar) olarak sınıflandırılmıştır. Bu çalışmada ayrıca plak psoriyazisli olgular "stabil", guttat psoriyazisli veya guttat saçılımları olan plak psoriyazisli olgular ise "aktif" psoriyazis olarak tanımlanmıştır. ${ }^{16}$

Dosyadaki verilerden olguların yaşı (erken erişkin 19-45 yaş, orta erişkin 46-64 yaş veya yaşlı $\geq 65$ yaş), psoriyazis başlangıç yaşı (erken $<40$ yaş veya geç $\geq 40$ yaş başlangıçı), hastalık süresi, ailede psoriyazis varlığı, lezyonlarda alevlenme varsa bu durumun ne kadar süre önce (son 1 ay, 1-3 ay, 3-6 ay veya 6-12 ay içinde ya da 12 aydan daha uzun bir süre önce) olduğu ile ilgili ayrıntılı öyküleri ve Psoriyazis Alan Şiddet Indeksi ("Psoriasis Area and Severity Index", PASI)'ne göre değerlendirilmiş olan klinik şiddet skorları kaydedilmiştir.
Çalışmaya dosyasında hemogram, eritrosit sedimentasyon hızı, Creaktif protein, rutin idrar analizi ve idrar kültürü bulunan olgular dahil edilmiştir. Genital infeksiyon açııından tüm olguların Kadın Hastalıkları bölümünce değerlendirilmiş ve genital infeksiyon tanısının bu bölümce konulmuş olması kriteri aranmıştır. Üriner infeksiyon açısından ise laboratuar bulguları üriner infeksiyonu düşündüren olguların üriner infeksiyon tanısının Üroloji bölümünce konulmuş olması kriteri aranmıştır. Dosya taraması doğrultusunda Güi varlığı ile ilgili bulgular kaydedilmiştir.

Veriler SPSS 15 sunumu kullanılarak analiz edilmiştir. Tanımlayıcı analiz ile sayısal değişkenler ortalamaıstandart sapma olarak, diğer değişkenlerin ise yüzde sıklıkları elde edilmiştir. Psoriyazis alt gruplarının kendi aralarında karşılaştırılmasında ve GÜi saptanan olguların demografik ve klinik parametrelerinin GÜi olmayan olgularla karşılaştırılmasında ki-kare, Fisher'in kesinlik testi ve t testi kullanılmıştır. İstatistiksel olarak $p<0,05$ olan değerler anlamlı olarak kabul edilmiştir.

\section{Bulgular}

Çalışma kapsamında değerlendirilen toplam 144 olgunun 93 $(\% 64,6)^{\prime}$ ünün aktif psoriyazis, $51(\% 35,4)^{\prime}$ inin ise stabil psoriyazis klinik özelliklerini taşıdığı saptanmıştır. Aktif psoriyazisli 93 olgunun ise $33(\% 35,5)^{\prime}$ ünü guttat psoriyazisli ve $60(\% 64,5)^{\prime} ı$ nı guttat saçı ımlı plak psoriyazisli olguların oluşturduğu belirlenmiştir. Çalışmaya alınan olguların demografik ve özgün klinik verileri Tablo 1'de gösterilmektedir. Totalde aktif ve stabil psoriyazisli olgular arasında karşılaştırma yapıldığında; yaş ortalamalarının aktif grupta anlamlı olarak daha düşük olduğu görülmüştür. Ayrıca istatistiksel olarak anlamlı derecede daha fazla olmak üzere aktif psoriyazisli olguların çoğunun erken erişkin $(\% 40,9)$ grubunda iken stabil psoriyazisli olguların çoğunun orta erişkin dönemde $(\% 62,7)$ olduğu belirlenmiştir. Ortalama hastalık süreleri, aile öyküsü varlığı ve ortalama PASı değerleri açısından her iki grup arasında anlamlı fark olmadığı, ancak aktif gruptaki olguların stabil gruptaki olgulara göre ortalama psoriyazis başlangıç yaşının daha düşük ve son alevlenme sürelerinin daha kısa olduğu saptanmıştır.

Çalışmaya alınan toplam 144 olgunun 48 (\%33,3)'inde GÜi saptanmış olup psoriyazis klinik alt tiplerine göre değerlendirildiğinde aktif psoriyazisli olgularda \%36,6 (GP'te \%33,3, guttat saçılımlı PP'te $\% 38,3$ ) oranında saptanan GÜi sıklığının stabil psoriyazisli olgularda \%27,5 olduğu belirlenmiştir. Aktif ve stabil olgular karşılaştırıldığında aktif olgularda istatistiksel olarak anlamlı olmamakla birlikte Güi sıklığında artış saptanmış olup, saptanan infeksiyonlar ve bunların klinik tiplere göre dağılımı Tablo 2'de gösterilmiştir.

Her bir psoriyazis alt grubunda GÜi saptanmayan olgularla saptanan olguların demografik ve psoriyazise özgün klinik verileri Tablo 3'de gösterilmektedir. Tüm olgular değerlendirildiğinde GÜi saptanan olgularla GÜi olmayanların ortalama yaşları arasında istatistiksel olarak anlamlı fark saptanmazken yaş grupları dağılımı açısından da farklılık izlenmemiştir. Aile öyküsü varlığı açısından fark belirlenmemekle birlikte GÜi olan olgularda ortalama hastalık süresinin anlamlı olarak daha uzun, başlangıç yaşının daha düşük ve son alevlenme süresinin daha kısa olduğu gösterilmiştir. Ortalama PASI değerlerinin GÜi olmayan olgulara göre anlamlı olarak daha yüksek olduğu ve PASı değeri $\geq 10$ olan olgularda GÜi varlığının arttığı görülmüştür. Psoriyazis alt tipleri açısından değerlendirildiğinde ise hem aktif hem de stabil grupta GÜi olan olgularla olmayanlar arasında yaş ortalaması, yaş grupları dağılımı ve aile öyküsü varlığı açısından anlamlı fark 


\section{Tablo 1. Aktif ve stabil psoriyazisli olguların demografik ve klinik özellikleri}

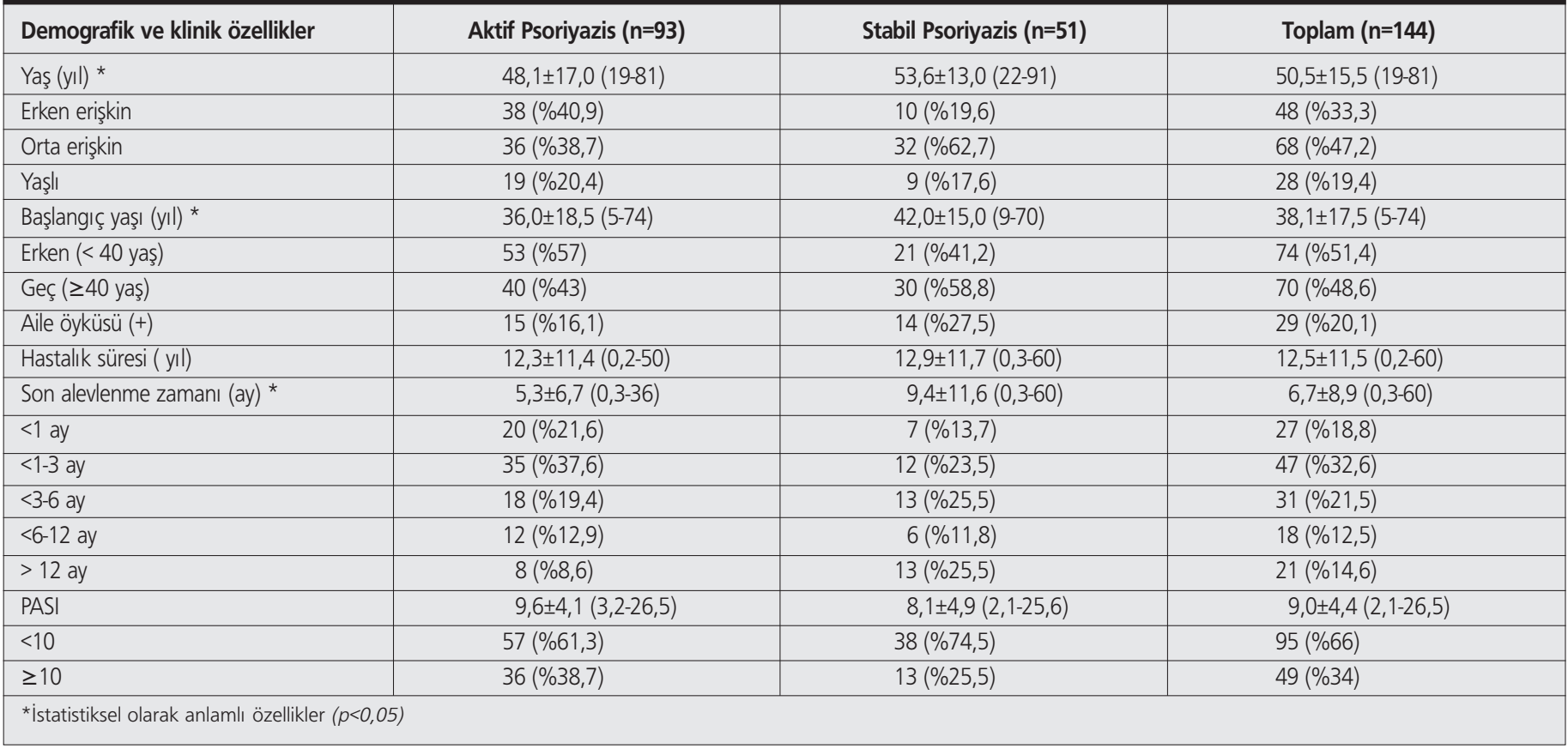

\section{Tablo 2. Aktif ve stabil psoriyazisli olgularda saptanan genitoüriner infeksiyonlar}

\begin{tabular}{|l|c|c|c|}
\hline Genitoüriner infeksiyonlar & Aktif Psoriyazis (n=93) & Stabil Psoriyazis (n=51) & Toplam (n=144) \\
\hline İdrar yolu infeksiyonu & $15(\% 16,1)$ & $6(\% 11,8)$ & $21(\% 14,6)$ \\
\hline Vajinit & $8(\% 8,6)$ & $4(\% 7,8)$ & $12(\% 8,3)$ \\
\hline idrar yolu infeksiyonu +vajinit & $7(\% 7,5)$ & $3(\% 5,9)$ & $10(\% 6,9)$ \\
\hline Servisit & $3(\% 3,2)$ & $1(\% 2,0)$ & $4(\% 2,8)$ \\
\hline Vajinit+servisit & $1(\% 1,1)$ & $0(\% 0)$ & $1(\% 0,7)$ \\
\hline Total & $34(\% 36,6)$ & $14(\% 27,5)$ & $48(\% 33,3)$ \\
\hline
\end{tabular}

\section{Tablo 3. Genitoüriner infeksiyon saptanan aktif ve stabil psoriyazisli olguların demografik ve klinik özellikleri}

Demografik ve klinik özellikler

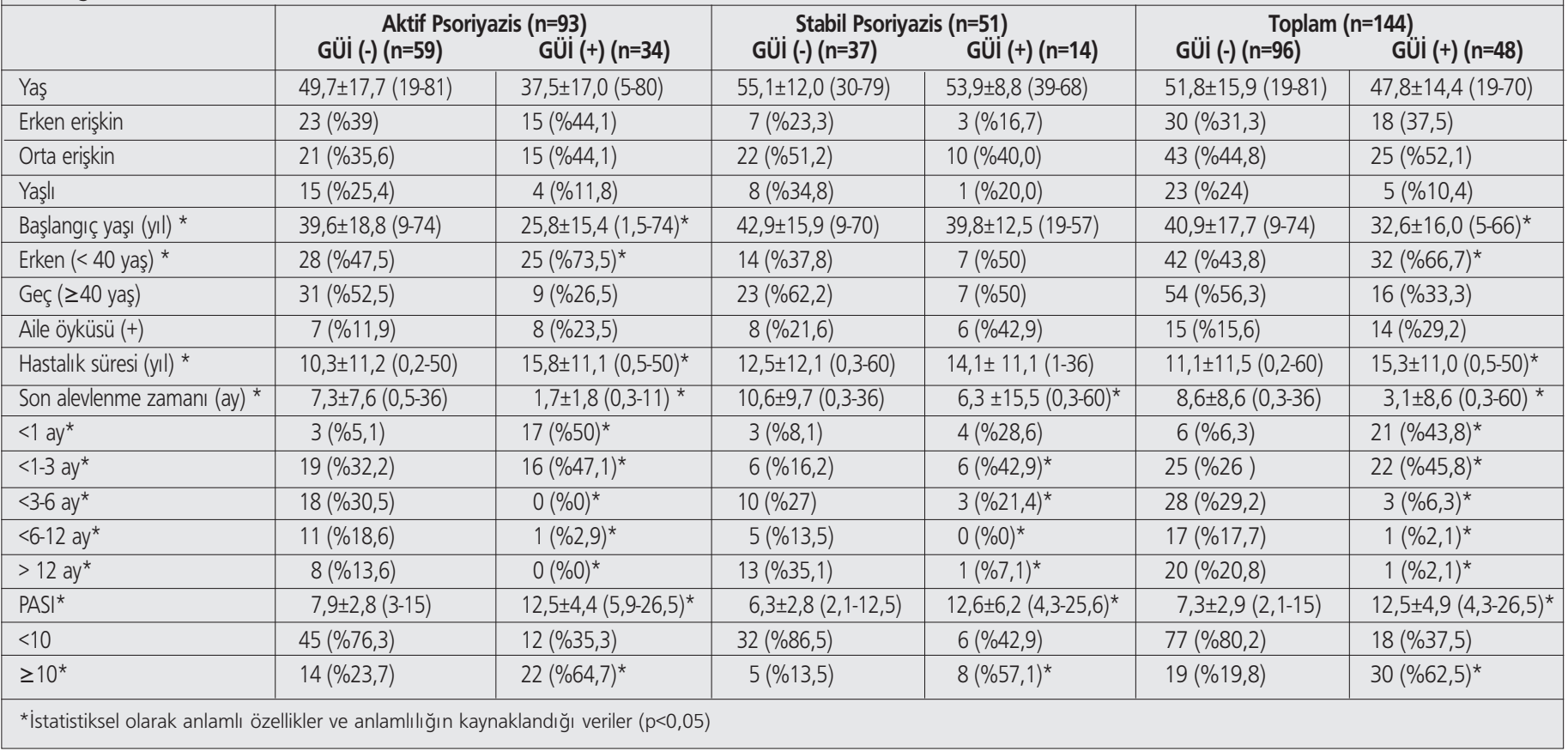


izlenmemiştir. Aktif grupta GÜi olan olgularda anlamlı olarak ortalama hastalık süresinin daha uzun, psoriyazis başlangıç yaşının daha düşük ve son alevlenme sürelerinin daha kısa olduğu görülmüştür. Aktif gruptaki GÜi'lu olguların yarısının son bir ay içinde alevlenme geçirmiş olduğu ve yakın zamanda alevlenmesi olan GÜi'lu olguların Güi olmayan olgulardan anlamlı olarak daha fazla olduğu görülmüştür. Stabil grupta son bir ay içinde alevlenme geçirmiş GÜi olan ve olmayan olgu sayıları açısından anlamlı fark olmamasına rağmen 1. aydan daha uzun süre önce alevlenmesi olan olgular arasında Güi'lu olguların anlamlı olarak daha fazla olduğu saptanmıştır. Her iki grupta da GÜi saptanan olgulardaki ortalama PASI değerlerinin GÜi olmayan olgulara göre anlamlı olarak daha yüksek olduğu ve PASı değeri $\geq 10$ olan olgularda GÜi varlığının arttığı görülmüştür.

\section{Tartışma}

Psoriyazis vulgarisli olguların çoğunluğunu oluşturan plak psoriyazis özellikle lumbosakral alan, saçlı deri, diz ve dirseklerde yoğunlaşmış üzeri sedefi beyaz renkli skuamla kaplı eritemli papüler lezyonlarla karakterizedir. Psoriyazisli olguların yaklaşık \%10'unu oluşturan guttat psoriyazis ise genellikle çocuklarda ve genç erişkinlerde görülen ve sıklıkla akut tonsillit veya farenjit gibi bir üst solunum yolu infeksiyonundan sonra birdenbire ortaya çıkan eritemli küçük papüler lezyonlarla karakterize psoriyazis tipidir. Guttat psoriyazis daha önceden psoriyazis öyküsü olmayan bir olguda ilk kez oluşabileceği gibi, genellikle sınırlı deri alanlarını tutan kronik plak psoriyazis lezyonlarına eşlik etmektedir. ${ }^{1-3}$ Psoriyazisin bu çeşitlilik gösteren klinik görünümlerinin tesadüfi veya sadece Koebner etkisi ile olmaktan ziyade, mikrobiyal uyaranın özelliği ve lokalizasyonuna bağlı olarak alternatif kompleman yolu aktivasyonu ile oluşabileceği ileri sürülmüştür. ${ }^{4,8} \mathrm{Biz}$ bu çalışmada guttat lezyonları olan olguları eşlik eden plak tarzı lezyonları olsa da aktif psoriyazis grubu içinde, sadece plak tarzı lezyonları olan olguları ise stabil psoriyazis grubu içinde değerlendirdik. ${ }^{16}$

Literatürde psoriyazisin başlaması, süregenliği ya da şiddetlenmesinde en çok suçlanan infeksiyöz ajanlar streptokoklar ve daha az oranda stafilokoklar olmakla birlikte, bazı yazarlar tarafından hastalığın alevlenmesinde daha geniş bir spektrum oluşturan bakteriyal, viral veya fungal kökenli farklı mikroorganizmaların rol oynadığı ileri sürülmüştür. Bunlar arasında en tutarlı ilişkinin psoriyazisin hem akut hem kronik formlarında suçlanmış olan A grubu beta hemolitik streptokoklar ile olduğu bildirilmiş, diğer mikrobiyal etkenlerin etyopatogenezde rolü olup olmadığı henüz kesinlik kazanmamıştır. ${ }^{5,7,12}$

Sonuç olarak, psoriyazisli olgularda bakteriyel veya viral süperantijenlerin normal immünolojik yolakları geçerek immün sistemde güçlü bir stimulasyona yol açabildiği ve psoriyazis gelişiminde en önemli rolü oluşturan T lenfositlerinin üretimine neden olduğu bilinmektedir.,12 Yakın zamanda Blok ve arkadaşları tarafından 45 psoriyazis olgusunda yapılmış olan ve son bir yıl içinde geçirilen tonsillit, farenjit, sinüzit, ürosistit ve diğer infeksiyonların psoriyazisle ilişkisinin sorgulandığı bir anket çalışmasında olguların \%33'ü infeksiyon sonrası psoriyaziste alevlenme olduğunu belirtmiş, ayrıca bu olgularda psoriyazis başlangıç yaşının diğer olgulara göre daha düşük olduğu gözlenmiştir. Suçlanan infeksiyonların sıklığıyla ilgili ayrıntılı veriler olmamakla birlikte, sıklık sırasına göre farenjit ve sinüziti alt idrar yolu infeksiyonlarının takip ettiği belirlenmiştir. ${ }^{13}$ Literatürdeki psoriyazis ile GÜi varlığı arasındaki ilişkiyi değerlendiren çalışmalar incelendiğinde sadece idrar yolu infeksiyonu ile ilgili sınırlı verilere rastlanmıştır. Illk kez Rosenberg ve arkadaşları tarafından bazı olgularda asemp- tomatik idrar yolu infeksiyonu tedavisi ile psoriyazis kliniğindeki düzelmenin gözlenmesi üzerine tüm olgulardan rutin idrar kültürü istendiği ve üreme belirlenen olguların psoriyazis kliniğinin daha yaygın ve aktif olduğu bildirilmiştir. Ayrıca farklı klinik tiplerdeki 167 psoriyazis olgusunda yapılan retrospektif bir çalışmada gövde ve ekstremitelerdeki küçük pembe plaklı psoriyazis klinik tipi ile idrar kültürü pozitifliği arasında istatistiksel olarak anlamlı bir ilişki olduğu saptanmıştır., Ürogenital traktustaki proteus mirabilis, escherichia coli ve diğer gram negatif basillerin etken olduğu rekürren infeksiyonlar ve düşük düzeydeki persistan kolonizasyonun klinik bulgularla birlikte değerlendirilerek tedavi edildiğinde psoriyazis lezyonlarındaki dramatik düzelmenin izlenmesi nedeniyle idrar yolu infeksiyonlarının tetikleyici faktör olarak dikkate alınması gerekliliği vurgulanmıştır., Bizim çalışmamızda ise olgularımızın \%33,3'ünde GÜi varlığı saptanmış olup, bunların $\% 21,5^{\prime}$ inde idrar yolu infeksiyonu, \%16'sında vajinit ve \%3,5'unda servisit belirlenmiştir.

Psoriyazis klinik tiplerinden özellikle guttat psoriyazis olmak üzere guttat saçılımlı ve stabil plak psoriyazisin, daha az oranda da püstüler psoriyazisin üst solunum yolu infeksiyonları, dental infeksiyonlar ve nadiren perianal infeksiyonlarla tetiklenebildiği bildirilmiştir. ${ }^{6,21-23}$ Literatürdeki psoriyazis klinik tipi ile infeksiyon varlığı arasındaki ilişkiyi değerlendiren çalışmalar çoğunlukla en sık görülen fokal infeksiyon olan üst solunum yolu infeksiyonu verilerine dayanmaktadır. ${ }^{17-20}$ Psoriyazisli olgulardaki boğaz infeksiyonlarındaki artmış sıklığın bu olguların tonsillerindeki anormal savunma mekanizması ile ilişkili olabileceği ileri sürülse de, diğer infeksiyonlara yatkınlığın artması ile ilgili yeterli kanıt bulunmamaktadır. ${ }^{17}$ Tonsillit ve farenjit gibi boğaz infeksiyonlarının psoriyazis klinik tiplerinden özellikle bizim aktif grup olarak nitelediğimiz guttat psoriyazis ve guttat saçılımlı plak psoriyazis ile ilişkili olabileceği bildirilmiştir. ${ }^{16-20}$ Yakın zamanda psoriyazisin farklı klinik tipleri arasında yapılan bir çalışmada guttat psoriyazisli olguların $\% 85,7$ 'sinde, guttat alevlenmeleri olan plak psoriyazisli olguların $\% 71,4^{\prime}$ ünde ve kronik plak psoriyazisli olguların \%66,6'sında streptekokkal, stafilokokkal, probionobacterium, exiguobacterium veya bacillus türüne ait DNA belirlenmiştir. ${ }^{16}$ Biz de çalışmamızda psoriyazisli olgularda GÜI sıklığını saptamayı ve GÜi varlığının psoriyazis klinik tipi ile ilişkisini değerlendirmeyi amaçladık. Bu çalışmada GÜi sıklığı aktif psoriyazisli olgularda \%36,6 ve stabil psoriyazisli olgularda \%27,5 oranında saptanmış olsa da, psoriyazis klinik tipi ile GÜi varlığı arasında istatistiksel olarak anlamlı bir fark saptanmamıştır.

Henseler ve Cristophers tarafından psoriyazisin erken başlangıçıı (<40 yaş) ailesel tipi ve geç başlangıçlı ( $\geq 40$ yaş) ailesel olmayan tipi olmak üzere iki tipinin olduğu belirtilmiştir. ${ }^{24}$ Boğaz infeksiyonlarının ailesinde psoriyazis öyküsü bulunan ve/veya başlangıç yaşı erken olan psoriyazis vulgarisli olgularda daha fazla saptandığı bildirilmiştir. ${ }^{22,24}$ Yine yeni bir alevlenmeden önce olası bir tetikleyici faktörün varlığı daha sık erken başlangıçlı psoriyazisli olgularda bildirilmiş, en sık suçlanan faktörler ise üst solunum yolu infeksiyonları ve iklimsel değişiklikler olmuştur. ${ }^{22}$ Bizim çalışmamızda ailesinde psoriyazis öyküsü bulunan olgulardaki GÜi sıklığında bir farklılık belirlenmemekle birlikte, literatüre benzer şekilde başlangıç yaşı erken olan ve yakın zamanda alevlenme geçirmiş olgularda GÜi'nun daha fazla görüldüğü belirlenmiştir.

Literatürde infeksiyon varlığı ile PASI değerleri arasındaki ilişkiyi araştıran çalışmalar yeterli olmasa da, boğaz kültüründe beta hemolitik streptekok üreyen plak psoriyazisli olgularda ve ASO değerleri yüksek olan plak psoriyazisli çocuk olgularda PASI değerlerinin anlamlı olarak daha yüksek olduğu bildirilmiştir. ${ }^{19,25}$ Bununla birlikte Yıldırım ve arkadaşları tarafından psoriyazis ve parvovirüs B19 arasındaki ilişkinin 
araştırıldığı bir diğer çalışmada viral DNA yükü ile psoriyazis klinik tipi ve PASI değerleri arasında anlamlı bir ilişki saptanmamıştır. ${ }^{26}$ Bizim çalışmamızda ise GÜi saptanan aktif ve stabil psoriyazisli olgularda GÜi olmayanlara göre ortalama PASI değerleri anlamlı olarak daha yüksek saptanmış, ayrıca her iki grupta da PASI değeri $\geq 10$ olan olgularda GÜi varlığının arttığı görülmüştür.

Aktif ve stabil psoriyazisli kadın olgularda GÜi sıklığının araştırıldığı bu çalışmanın retrospektif nitelikte olması, olgu sayısının çok fazla olmaması ve yatan hasta kümesini içerdiği için herhangi bir inflamatuvar hastalığı olmayan kontrol grubunun dahil edilememiş olması çalışmamızın sınırlılıkları arasındadır.

Sonuç olarak; bu çalışmada aktif psoriyazisli olgulardaki GÜi sıklığının stabil olgulara göre kısmen daha fazla olmakla birlikte bu farkın istatististiksel olarak anlamlı olmadığı gözlenmiştir. Bununla birlikte hem aktif hem de stabil psoriyaziste özellikle yakın zamanda alevlenme geçirmiş veya klinik şiddet skorları yüksek olan olgularda Güi araştırılmasının uygun olacağı kanaatindeyiz.

\section{Kaynaklar}

1. Naldi L, Gambini D: The clinical spectrum of psoriasis. Clin Dermatol 2007;25:510-8.

2. Griffiths CE, Barker JN: Pathogenesis and clinical features of psoriasis Lancet 2007;370:263-71.

3. Gürer MA, Adışen E: Psoriasis, introduction, general information, epidemiology. Türkderm 2008;42:15-7.

4. Rosenberg EW, Noah PW, Skinner RB Jr, Vander Zwaag R, West SK, Browder JF: Microbial associations of 167 patients with psoriasis. Acta Derm Venereol Suppl (Stockh) 1989;146:72-4.

5. Fry L, Baker BS: Triggering psoriasis: the role of infections and medications. Clin Dermatol 2007;25:606-15.

6. Tagami H: Triggering factors. Clin Dermatol 1997;15:677-85.

7. Fry L: Role of microbes in psoriasis. Clin Exp Dermatol 2000;25:164.

8. Rosenberg EW, Noah PW, Skinner RB Jr: Microorganisms and psoriasis. J Natl Med Assoc 1994;86:305-10.

9. Noah PW: The role of microorganisms in psoriasis. Semin Dermatol 1990;9:269-76.

10. Rigopoulos D, Gregoriou S, Katrinaki A, Korfitis C, Larios G, Stamou C, et al: Characteristics of psoriasis in Greece: an epidemiological study of a population in a sunny Mediterranean climate. Eur J Dermatol 2010;20:189-95
11. Norholm-Pedersen A: Infections and psoriasis; a preliminary communication. Acta Derm Venereol 1952;32:159-67.

12. Owen CM, Chalmers RJ, O'Sullivan T, Griffiths CE: A systematic review of antistreptococcal interventions for guttate and chronic plaque psoriasis. Br J Dermatol 2001;145:886-90.

13. Blok S, Vissers WH, van Duijnhoven M, van de Kerkhof PC: Aggravation of psoriasis by infections: a constitutional trait or a variable expression? Eur J Dermatol 2004;14:259-61.

14. Dielubanza EJ, Schaeffer AJ: Urinary tract infections in women. Med Clin North Am 2011;95:27-41.

15. Russell MW, Mestecky J: Tolerance and protection against infection in the genital tract. Immunol Invest 2010;39:500-25.

16. Munz OH, Sela S, Baker BS, Griffiths CE, Powles AV, Fry L: Evidence for the presence of bacteria in the blood of psoriasis patients. Arch Dermatol Res 2010;302:495-8.

17. Nahary L, Tamarkin A, Kayam N, Sela S, Fry L, Baker B, et al: An investigation of antistreptococcal antibody responses in guttate psoriasis. Arch Dermatol Res 2008;300:441-9.

18. Caca-Biljanovska NG, V'lckova-Laskoska MT: Management of guttate and generalized psoriasis vulgaris: prospective randomized study. Croat Med J 2002;43:707-12

19. Gudjonsson JE, Thorarinsson AM, Sigurgeirsson B, Kristinsson KG, Valdimarsson $\mathrm{H}$ : Streptococcal throat infections and exacerbation of chronic plaque psoriasis: a prospective study. Br J Dermatol 2003;149:530-4.

20. Bartenjev I, Rogl Butina M, Potocnik M: Subclinical microbial infection in patients with chronic plaque psoriasis. Acta Derm Venereol Suppl (Stockh) 2000;211:17-8.

21. Seyhan M, Coşkun BK, Sağlam H, Ozcan H, Karincaoğlu Y: Psoriasis in childhood and adolescence: evaluation of demographic and clinical features. Pediatr Int 2006;48:525-30.

22. Raychaudhuri SP, Gross J: A comparative study of pediatric onset psoriasis with adult onset psoriasis. Pediatr Dermatol 2000;17:174-8.

23. Adışen E, Tekin Ö, Gülekon A, Gürer MA: Çocukluk dönemi psoriazisi: 130 olgunun retrospektif değerlendirmesi. Türk Dermatoloji Dergisi 2008;2:43-6.

24. Henseler T, Christophers E: Psoriasis of early and late onset: characterization of two types of psoriasis vulgaris. J Am Acad Dermatol 1985;13:450-6.

25. Kim SK, Kang HY, Kim YC, Lee ES: Clinical comparison of psoriasis in Korean adults and children: correlation with serum anti-streptolysin $\mathrm{O}$ titers. Arch Dermatol Res 2010;302:295-9.

26. Yıldırım M, Ceyhan AM, A, Arıdoğan BC, Koç IG, Kaya S: Investigation of relationship between Parvovirus B19 infection and psoriasis. Türkderm 2010;44:200-203. 